\title{
Molecular Characterization of Soybean Genotypes in Response to Charcoal Rot Disease by using SSR Markers
}

\author{
S. V. Chavan ${ }^{1 *}$, P. V. Jadhav ${ }^{2}$, M. S. Madke ${ }^{2}$, S. S. Mane ${ }^{3}$ and R. S. Nandanwar ${ }^{1}$ \\ ${ }^{1}$ Department of Agricultural Botany, ${ }^{2}$ Department of Agricultural Biotechnology, ${ }^{3}$ Department \\ of Plant Pathology, Dr. PDKV, Akola, India \\ *Corresponding author
}

\section{A B S T R A C T}

\section{Keywords}

Soybean, Charcoal rot, Inheritance, SSR, Validation

Article Info

Accepted:

04 September 2019

Available Online:

10 October 2019
Charcoal rot (CR) disease caused by Macrophomina phaseolina is responsible for significant yield losses in soybean production. Among the methods available for controlling this disease, breeding for resistance is the most promising. The present study helped to evaluate soybean genotypes for identifying promising genotypes which proved to be resistant to charcoal rot. The present study was carried out at Department of Agricultural Botany, Dr. Panjabrao Deshmukh Krishi Vidyapeeth, Akola during the year 2018-19 to evaluate various genotypes of soybean for charcoal rot resistance. Charcoal rot disease caused by Macrophomina phaseolina is one of the most damaging diseases of soybean resulting to $70 \%$ losses and till date no immune genotype is known for the same. Molecular characterization of these genotypes was done by using SSR markers. Molecular profiles revealed remarkable polymorphism and observations showed that in total 143 amplicons were tested with an average of 6.22 alleles per locus. Out of the total screened alleles 49 were monomorphic alleles with an average of 2.13 and 94 were polymorphic alleles with an average of 4.09. Results showed an average of 65.97 polymorphism percent. The PIC (Polymorphic information content) value of 23 microsatellite loci ranged from 0.30 to 0.84 with an average value of 0.70 ,these studies will help in mapping studies and breeding program for development of charcoal rot resistance in soybean genotypes which will be of utmost importance.

\section{Introduction}

Soybean [Glycine max (L.) Merrill] designated as miracle bean established its potential as an industrially vital and viable oilseed crop in many areas of India. It is the cheapest source of vegetable oil and protein. It contains about 40 percent protein, well balanced in essential amino acids, 20 percent oil rich with poly unsaturated fatty acid specially omega 6 and Omega 3 fatty acids, 6-7 percent total mineral, 5-6 percent crude fiber and 17-19 percent carbohydrates (Chauhan and Opena,1988). It is not only used for human consumption, but also used to produce lowcost, high protein feed ingredients. It also finds wider 
application in industry to produce numbers of products and services for human uses.

Among the biotic challenges, charcoal rot disease is the most serious one. It is caused by fungus Macrophomina phaseolina (Tassi) Goid., a soil borne pathogen distributed worldwide with a host range of more than 500 plant species of both monocots and dicots (Mihail and Taylor, 1995).The destructive attack of $\mathrm{M}$ phaseolina has been more pronounced during the drought/ drought like situations that often prevails during crop growing period due to early withdrawal of the monsoon. The disease can attack the soybean plants at any stage of development- from the seedling stage all the way through maturity. After attack, the plant loses its vigor; turn yellow, wilt and drop leaves early. It results in poor pod setting, improper seed filling and eventual loss of yield. It can create a yield loss of $10-50 \%$ in years with prime weather conditions. However, it may go up to $70 \%$ in severe cases (Almeida et al., 2001; Yang and Navi, 2005).

Control of charcoal rot disease through cultural and chemical means was found neither effective nor economical. The genome of soybean has been fully sequenced and various classes of molecular markers are in abundance. The most abundant markers developed for soybean includes RFLP markers (Apuya et al., 1988; Keim et al., 1989), simple sequence repeat (SSR) (Akkaya et al., 1995), amplified fragment length polymorphism (AFLP) markers (Keim et al., 1997) and single nucleotide polymorphism (SNP) markers (Choi et al., 2007). However, the SSR markers have been widely used in gene and QTL mapping studies in soybean because of its higher level of polymorphism, user-friendly nature, multiple allele per locus and specificity (Netu et al., 2007).Genetic resistance has therefore been promoted through deployment of resistant or tolerant genotypes. However, genotype with higher level of resistance is not available yet for commercial cultivation (Mengistu et al., 2011). Breeding for charcoal rot resistance met with little success primarily due to absence of robust screening technique and unclear inheritance pattern of the disease resistance in the host plants. It indicates importance of finding linked molecular markers for effective and efficient screening. In this study, attempt was made to study the inheritance pattern and mapping of charcoal rot resistance in soybean.

\section{Materials and Methods}

\section{Plant material}

A set of 14 diverse soybean genotypes were used for screening. The collected genotypes included promising varieties, indigenous, mutants, few pre released collections, advanced breeding lines as well as obsolete varieties. It varied in maturity, seed color, flower colour, seed size, and reaction to charcoal rot disease as well as other yield attributing traits. Specific features of the genotypes are presented in Table 1.

\section{Selection of markers for polymorphism and genotyping}

Simple sequence repeat markers are being extensively validated in scientific literature and extensively used in genome studies and marker assisted selection and are well-known for their versatility in providing a quick assay and for their highly informative data. In the light of above facts and the hypothesis that molecular markers are more efficient than morphological markers for verification of soybean varieties, a set of total 23 SSR markers were used in this study. The markers were selected from across the soybean genome. The sequences of the markers were downloaded from soybase (www.soybase.org) and synthesized through local vendors 
(www.idtdna.com)The sequences and related information about the SSR primers have been given in Table 2.

\section{DNA isolation and $\mathrm{PCR}$ reactions}

Genomic DNA of the 14 genotypes was extracted from seed powder using the Dellaporta method described by Stephen L. Dellaporta 1983 with minor modifications. All PCR reactions were performed within a total volume of 20ul in 96-well plates using Eppendorf thermocycler. PCR reaction mixture containing $10 \mathrm{X}$ PCR buffer (Himedia), $\quad 10 \mathrm{mM}$ of each deoxyribonucleotide triphosphate (Himedia), $5 \mathrm{U}$ of Taq polymerase (Himedia), and $10 \mathrm{pcm}$ of primer. The PCR amplifications of the genotypes were performed in a $20 \mu 1$ reaction volume. Each reaction contained template genomic DNA. A standard PCR cycle was used with an initial denaturation step at $94^{\circ} \mathrm{C}$ for $5 \mathrm{~min}$ followed by 35 cycles of $94^{\circ} \mathrm{C}$ for 1 $\min , 50^{\circ}-60^{\circ} \mathrm{C}$ for $30 \mathrm{sec}$, and $72^{\circ} \mathrm{c}$ for $1 \mathrm{~min}$; the final extension at $72^{\circ} \mathrm{c}$ was held for $5 \mathrm{~min}$ and hold at $4^{\circ} \mathrm{C}$. The annealing temperatures however, varied from primer to primer; hence optimization was done wherever required. Analysis of the amplified PCR products were further analyzed with the help of PAGE (Plate 1)

\section{Results and Discussion}

Molecular characterization was done by using SSR primers and amplicons were scored as present (1) and absent (0) or as a missing observation for each genotype. Genotypes were assigned a null allele for a microsatellite locus, whereas, an amplification product could not be decreased for a particular genotype.

The reaction of the marker was measured and the Polymorphism Information content (PIC) and polymorphic\% were calculated using software available at (www.liverpool.ac.uk.).
The frequency of the null allele was not included in the calculation of PIC value and polymorphic percentage as given in Table 3

Highest polymorphism was seen in primer Satt130 (88.89\%) followed by Satt542 $(85.71 \%)$. Lowest polymorphism was seen in primers Satt524 and Satt230 (42.86\%). Observations showed that in total 143 amplicons were tested with an average of 6.22 alleles per locus. Out of the total screened alleles 49 were monomorphic alleles with an average of 2.13 and 94 were polymorphic alleles with an average of 4.09. Results showed an average of 65.97 polymorphism percent. The PIC (Polymorphic information content) value of 23 microsatellite loci ranged from 0.30 to 0.84 with an average value of 0.70 ,these studies will help in mapping studies and breeding program for development of charcoal rot resistance in soybean genotypes.

Selective genotyping may be useful to see the association between genetic diversity and phylogenetic data, otherwise segregating population will have to screen. However, point mutations cannot be/very rarely detected by the SSR marker, considering this different approaches like single stranded confirmation polymorphism (SSCP), Endonucleolytic Mutation Analysis by Internal Labelling (EMAIL), High resolution melting (HRM), Heteroduplex, should be used to investigate the important point mutation in functional gene.

The polymorphic marker identified in the present investigation for the characterization of promising genotypes can be further explored to see the association with any desired character. Soybean genetic diversity analysis showed greater degree of polymorphism and better discrimination between varieties for microsatellite markers. 
Table.1 Soybean genotypes included in the study

\begin{tabular}{|c|c|c|c|}
\hline S.N & Genotypes & Parents & Remarks \\
\hline 1 & AMS MB 5-19 & Mutant of Bragg & $\begin{array}{l}\text { Developed by Mutation breeding and characteristically } \\
\text { fixed at M8 generation. }\end{array}$ \\
\hline 2 & AMS MB 5-18 & Mutant of Bragg & $\begin{array}{l}\text { Developed by Mutation breeding and characteristically } \\
\text { fixed at M8 generation. }\end{array}$ \\
\hline 3 & AMS - 1001 & Mutants & Pre released variety \\
\hline 4 & AMS - 77 & Mutant of JS 93-05 & $\begin{array}{c}\text { Developed by Mutation breeding and characteristically } \\
\text { fixed at M5 generation. }\end{array}$ \\
\hline 5 & AMS - 353 & Mutants & Pre released variety \\
\hline 6 & AMS - 358 & Mutant of JS 93-05 & $\begin{array}{c}\text { Developed by Mutation breeding and characteristically } \\
\text { fixed at M5 generation. }\end{array}$ \\
\hline 7 & BRAGG & Parental genotype & Parental genotypes \\
\hline 8 & AMS - 243 & Mutant of Bragg & $\begin{array}{c}\text { Developed by Mutation breeding and characteristically } \\
\text { fixed at M8 generation. }\end{array}$ \\
\hline 9 & JS - 93-05 & Parental genotype & Parental genotypes \\
\hline 10 & AMS 99-33 & Mutants & Pre released variety \\
\hline 11 & AMS 38-24 & TAMS $38 \times$ RKS 24 & Recombinant breeding, entry fixed at F2 generation. \\
\hline 12 & AMS -475 & Mutant of JS 93-05 & $\begin{array}{c}\text { Developed by Mutation breeding and characteristically } \\
\text { fixed at M5 generation. }\end{array}$ \\
\hline 13 & $\mathrm{JS}-335(\mathrm{R})$ & (Check-Resistant) & High yielding variety, most popular \\
\hline 14 & TAMS -38 (S) & (Check-Susceptible) & Highly susceptible variety \\
\hline
\end{tabular}

$\mathrm{R}=$ Check Resistant; $\mathrm{S}=$ Check Susceptible 
Table.2 List of SSR primers used in experiment

\begin{tabular}{|c|c|c|c|c|c|}
\hline SN & Primers & Position & Nucleotide sequence & BP & $\mathbf{C N}$ \\
\hline \multirow[t]{2}{*}{1} & \multirow[t]{2}{*}{ Satt542 } & Forward & CACCAGCACAGAACAATCATTT & 22 & 2 \\
\hline & & Reverse & CACGGTCTAACCTTTCCTTCTA & 22 & \\
\hline \multirow[t]{2}{*}{2} & \multirow[t]{2}{*}{ Satt189 } & Forward & CCATACGCAGCATTAGAG & 18 & 2 \\
\hline & & Reverse & GCTATTTGCATGTTGAGAA & 19 & \\
\hline \multirow[t]{2}{*}{3} & \multirow[t]{2}{*}{ Sat_289 } & Forward & GCGAATTCCAGCTTTTATCACTTTATGAC & 29 & 2 \\
\hline & & Reverse & GCGATTGGAAAGTGCCTTTTATGTT & 25 & \\
\hline \multirow[t]{2}{*}{4} & \multirow[t]{2}{*}{ Satt524 } & Forward & GCGAATTATCCAAAGATACACTTAGTC & 27 & 4 \\
\hline & & Reverse & GCGGGTCTTACGAACGTGTCACATTAT & 27 & \\
\hline \multirow[t]{2}{*}{5} & \multirow[t]{2}{*}{ Satt164 } & Forward & CACCAATGGCTAAAGGTACATAT & 23 & 4 \\
\hline & & Reverse & AGGAGAAGAAAAAATCACATAAAATATC & 28 & \\
\hline \multirow[t]{2}{*}{6} & \multirow[t]{2}{*}{ Satt640 } & Forward & AGATACCTACGGAGTGTTTTTT & 22 & 6 \\
\hline & & Reverse & GGTTCCCCGGTGGCTACACAAC & 22 & \\
\hline \multirow[t]{2}{*}{7} & \multirow[t]{2}{*}{ Satt643 } & Forward & CGGGATAAATAGAAGTGGAACA & 22 & 6 \\
\hline & & Reverse & TTGGCAAATGTGAAATGTATA & 21 & \\
\hline \multirow[t]{2}{*}{8} & \multirow[t]{2}{*}{ Satt202 } & Forward & GGAATGCATGAGTATTAACCTCTTAT & 26 & 6 \\
\hline & & Reverse & GGGCTAACGAACATGTAACTTATCAAC & 27 & \\
\hline \multirow[t]{2}{*}{9} & \multirow[t]{2}{*}{ Sat_087 } & Forward & AAGATTATTTTTGGTGAGTTG & 21 & 9 \\
\hline & & Reverse & AAGCACTAGTTATGAATCAATG & 22 & \\
\hline \multirow[t]{2}{*}{10} & \multirow[t]{2}{*}{ Satt242 } & Forward & GCGTTGATCAGGTCGATTTTTATTTGT & 27 & 9 \\
\hline & & Reverse & GCGAGTGCCAACTAACTACTTTTATGA & 27 & \\
\hline \multirow[t]{2}{*}{11} & \multirow[t]{2}{*}{ Satt070 } & Forward & TAAAAATTAAAATACTAGAAGACAAC & 26 & 14 \\
\hline & & Reverse & TGGCATTAGAAAATGATATG & 20 & \\
\hline \multirow[t]{2}{*}{12} & Satt556 & Forward & GCGATAAAACCCGATAAATAA & 21 & 14 \\
\hline & & Reverse & GCGTTGTGCACCTTGTTTTCT & 21 & \\
\hline 13 & Satt691 & Forward & GCGAAAGATAAAAAGTAGATTGAAA & 25 & 15 \\
\hline & & Reverse & GCGCTCCTAAATCCAAATGAATC & 23 & \\
\hline 14 & Satt483 & Forward & GCGGACACGAAATTTTAATTATT & 23 & 15 \\
\hline & & Reverse & GTCTCAACTCTCCGACACCTACTT & 24 & \\
\hline 15 & Satt230 & Forward & CCGTCACCGTTAATAAAATAGCAT & 24 & 15 \\
\hline & & Reverse & СТСССССАААТТТААССТТАAАGA & 24 & \\
\hline 16 & Satt414 & Forward & GCGTATTCCTAGTCACATGCTATTTCA & 27 & 16 \\
\hline & & Reverse & GCGTCATAATAATGCCTAGAACATAAA & 27 & \\
\hline 17 & Satt183 & Forward & TAGGTCCCAGAATTTCATTG & 20 & 16 \\
\hline & & Reverse & CACCAACCAGCACAAAA & 17 & \\
\hline 18 & Satt038 & Forward & GGGAATCTTTTTTTCTTTCTATTAAGTT & 28 & 18 \\
\hline & & Reverse & GGGCATTGAAATGGTTTTAGTCA & 23 & \\
\hline 19 & Satt130 & Forward & TAAACGAAATTTAGTTTTAAGACT & 24 & 18 \\
\hline & & Reverse & TGAATGGCTAAAAACGTGATT & 21 & \\
\hline 20 & Satt451 & Forward & GCGCAATTAAAAGGATAACTTATATC & 26 & 20 \\
\hline & & Reverse & CCCCTCTTTGGCCCTCACACCTTCTC & 26 & \\
\hline 21 & Satt354 & Forward & GCGAAAATGGACACCAAAAGTAGTTA & 26 & 20 \\
\hline & & Reverse & GCGATGCACATCAATTAGAATATACAA & 27 & \\
\hline 22 & Satt049 & Forward & GCGTCTATTCTTTTATGTGTTTATCTTAG & 29 & 20 \\
\hline & & Reverse & GCGTTATTTTTACAGAAACTCACCTA & 26 & \\
\hline 23 & Sat_104 & Forward & CCCTTGACAACCTTTTTAC & 19 & 20 \\
\hline & & Reverse & ACGAGTTGCTACAAATGAAT & 20 & \\
\hline
\end{tabular}


Table.3 Molecular characterization of selected soybean genotypes using SSR primers

\begin{tabular}{|c|l|c|c|c|c|c|}
\hline SN & Primer & $\begin{array}{c}\text { No. of } \\
\text { amplicon }\end{array}$ & $\begin{array}{c}\text { Monomorphic } \\
\text { alleles }\end{array}$ & $\begin{array}{c}\text { Polymorphic } \\
\text { alleles }\end{array}$ & $\begin{array}{c}\text { Polymorphism } \\
(\mathbf{\%})\end{array}$ & $\begin{array}{c}\text { PIC } \\
\text { value }\end{array}$ \\
\hline $\mathbf{1}$ & Satt189 & 7 & 3 & 4 & 57.14 & 0.8396 \\
\hline $\mathbf{2}$ & Satt542 & 7 & 1 & 6 & 85.71 & 0.8102 \\
\hline $\mathbf{3}$ & Sat_289 & 4 & 1 & 3 & 75.00 & 0.7031 \\
\hline $\mathbf{4}$ & Satt164 & 6 & 2 & 4 & 66.67 & 0.8102 \\
\hline $\mathbf{5}$ & Satt524 & 7 & 4 & 3 & 42.86 & 0.768 \\
\hline $\mathbf{6}$ & Satt643 & 5 & 1 & 4 & 80.00 & 0.4413 \\
\hline $\mathbf{7}$ & Satt202 & 6 & 3 & 3 & 50.00 & 0.7187 \\
\hline $\mathbf{8}$ & Sat_087 & 8 & 4 & 4 & 50.00 & 0.7201 \\
\hline $\mathbf{9}$ & Satt242 & 6 & 1 & 5 & 83.33 & 0.2955 \\
\hline $\mathbf{1 0}$ & Satt640 & 6 & 1 & 5 & 83.33 & 0.7031 \\
\hline $\mathbf{1 1}$ & Satt691 & 5 & 1 & 4 & 80.00 & 0.7033 \\
\hline $\mathbf{1 2}$ & Satt483 & 6 & 1 & 5 & 83.33 & 0.4939 \\
\hline $\mathbf{1 3}$ & Satt070 & 4 & 2 & 2 & 50.00 & 0.7031 \\
\hline $\mathbf{1 4}$ & Satt556 & 7 & 3 & 4 & 57.14 & 0.8102 \\
\hline $\mathbf{1 5}$ & Satt483 & 6 & 3 & 3 & 50.00 & 0.768 \\
\hline $\mathbf{1 6}$ & Satt414 & 7 & 3 & 4 & 57.14 & 0.7858 \\
\hline $\mathbf{1 7}$ & Satt230 & 7 & 4 & 3 & 42.86 & 0.8394 \\
\hline $\mathbf{1 8}$ & Satt183 & 7 & 3 & 4 & 57.14 & 0.8396 \\
\hline $\mathbf{1 9}$ & Satt038 & 6 & 1 & 5 & 83.33 & 0.7031 \\
\hline $\mathbf{2 0}$ & Satt130 & 9 & 1 & 8 & 88.89 & 0.7217 \\
\hline $\mathbf{2 1}$ & Satt451 & 6 & 2 & 4 & 66.67 & 0.7047 \\
\hline $\mathbf{2 2}$ & Satt354 & 6 & 2 & 4 & 66.67 & 0.5957 \\
\hline $\mathbf{2 3}$ & Satt049 & 5 & 2 & 3 & 60.00 & 0.7048 \\
\hline $\mathbf{-}$ & Total & $\mathbf{1 4 3}$ & $\mathbf{4 9}$ & $\mathbf{9 4}$ & $\mathbf{1 5 1 7 . 2 2}$ & $\mathbf{1 6 . 8}$ \\
\hline $\mathbf{-}$ & Average & $\mathbf{6 . 2 2}$ & $\mathbf{2 . 1 3}$ & $\mathbf{4 . 0 9}$ & $\mathbf{6 5 . 9 7}$ & $\mathbf{0 . 7 0}$ \\
\hline & & & & & & \\
\hline
\end{tabular}


Plate.1 Electrophoresis banding pattern of PCR amplified product resolved on $10 \%$ PAGE

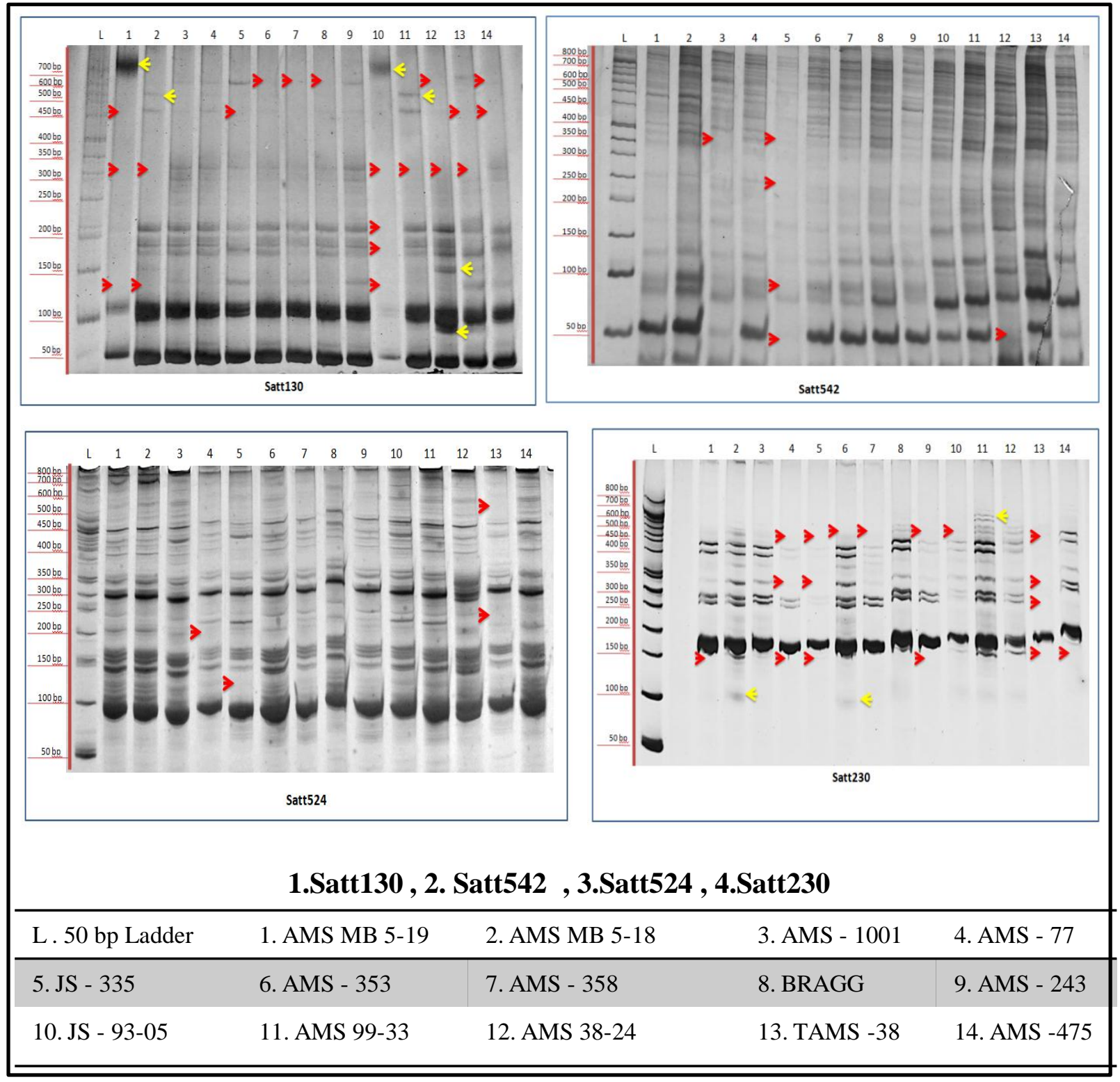

SSR markers are effective and reliable tools for analysis of genetic relationship among cultivars and selection of better soybean lines for further research work.

\section{References}

Akkaya M.S., Shoemaker R.C., Specht J.E., Bhagwat A.A. and Cregan P.B. 1995. Integration of simple sequence DNA markers into a soybean linkage map.
Crop Sci. 35: 1439-1445.

Almeida, A.M.R., Torres, E., Farias, J.R.B., Benato, L.C., Pinto, M.C. and Martin, S.R.R. 2001. Macrophomina phaseolina in soybean: effect of tillage system, survival on crop residues and genetic diversity. Londrina PR Embrapa Soja Circular Tecnica no, 34: 47.

Apuya, N.R., Frazier, B.L., Keim, P., Roth, E.J. and Lark, K.G. 1988. Restriction 
fragment length polymorphisms as genetic markers in soybean Glycine $\max$ L. Merrill. Theor. Appl. Genet. 75: 889-901.

Chauhan, B.S. and Opena, J.L. 1988. Effect of plant spacing on growth and grain yield of soybean. American J. plant Sci., 4(10): 2011-2014.

Choi, I.Y., Hyten, D.L., Matukumalli, L.K., Song, Q.J. et al., 2007. A soybean transcripot map: gene distribution, haplotype and single-nucleotide polymorphism analysis. Genetics 176 : 685-696.

Keim P., Schupp, J.M., Travis, S.E., Clayton, K., Zhu, T., Shi, L., Ferreira, A. and Webb, D.M. 1997. A high density soybean genetic map based on AFLP markers. Crop Sci. 37: 537-543.

Keim, P., Shoemaker, R.C., Palmer, R.G. 1989. Restriction fragment length polymorphism diversity in soybean. Theor. Appl. Genet. 77: 786-792.

Mengistu, A., Arelli, P.A., Bond, J.P., Shannon, G.J., Wrather, A.J., Rupe, J.B., Chen, P., Little, C.R., Canaday, C.H., Newman, M.A., and Pantalone,
V.R. 2011. Evaluation of soybean genotypes for resistance to charcoal rot. Online. Plant Health Progress. doi:10.1094/PHP- 2010-0926-01-RS.

Mihail, J.D. and Taylor, S.J. 1995. Interpreting variability among isolates of Macrophomina phaseolina in pathogenicity, pycnidium production and chlorate utilization. Can. J. Bot., 73: $1596-1603$.

Netu Ald-F., Hashmi, R., Schmidt, M., Carlson, S.R., Hartman, G.L. Li, S., Nelson, R.L. Diers, B.W. 2007. Mapping and confirmation of a new sudden death syndrome resistance QTL on linkage group D2 from the soybean genotypes PI567374 and 'Ripley'. Mol. Breed. 20: 53-62.

Stephen L. Dellaporta, Jonathan Wood, James B. Hicks. A plant DNA minipreparation: Version II. Plant Molecular Biology Reporter, 1983, Volume 1, Issue 4, pp 19-21.

Yang, X.B and Navi, S.S. 2005. First report of charcoal rot epidemics caused by Macrophomina phaseolina in soybean in Iowa. Pl. Dis., 89(5): 526.

\section{How to cite this article:}

Chavan, S. V., P. V. Jadhav, M. S. Madke, S. S. Mane and Nandanwar, R. S. 2019. Molecular Characterization of Soybean Genotypes in Response to Charcoal Rot Disease by using SSR Markers. Int.J.Curr.Microbiol.App.Sci. 8(10): 393-400. doi: https://doi.org/10.20546/ijcmas.2019.810.041 